

HISTORY EDUCATION RESEARCH JOURNAL

ISSN: 2631-9713 (Online)

Journal homepage:

https://www.ingentaconnect.com/content/ioep/herj

\title{
Using films in the development of historical consciousness: Research, theory and teacher practice
}

Debra Donnelly (iD

\section{How to cite this article}

Donnelly, D. (2020) 'Using films in the development of historical consciousness: Research, theory and teacher practice'. History Education Research Journal, 17 (1), 114-31. DOI https://doi.org/10.18546/HERJ.17.1.09

Submission date: 16 September 2019

Acceptance date: 10 December 2019

Publication date: 1 April 2020

\section{Peer review}

This article has been peer reviewed through the journal's standard double-blind peer review, where both the reviewers and authors are anonymized during review.

\section{Copyright}

(C) Copyright 2020 Donnelly. This is an Open Access article distributed under the terms of the Creative Commons Attribution Licence (CC BY) 4.0 https://creativecommons.org/licenses/ by/4.0/, which permits unrestricted use, distribution and reproduction in any medium, provided the original author and source are credited.

\section{Open access}

The History Education Research Journal is a peer-reviewed open-access journal. 


\title{
Using films in the development of historical consciousness: Research, theory and teacher practice
}

\author{
Debra Donnelly* - University of Newcastle, Australia
}

\begin{abstract}
In the digitally reliant twenty-first century, the exclusivity of printed sources for investigating and interpreting the past has been eroded, and other modes of historical interpretations, such as film, virtual reality simulations and online museums, have found a growing audience and influence. History education has followed suit in Australia, with a range of multimodal sources commonly featured in history teaching programmes (Donnelly, 2018). Film has become an increasingly popular choice as teachers strive to engage a student population accustomed to multimodality, and with technological upgrades facilitating viewings in learning spaces (Donnelly, 2014a). Using data from history teacher practice studies, this paper argues that films have the potential to impact historical consciousness, and proposes a model of the pedagogical mechanisms at work in these instances. Implementation strategies and practices are further illustrated by reference to two teaching protocol exemplars, the weekly plans of which are included in the paper.
\end{abstract}

Keywords: films; historical consciousness; qualitative research; empathy; values; history pedagogy

\section{Introduction}

In the digitally reliant twenty-first century, the exclusivity of printed sources for investigating and interpreting the past has been eroded, and other modes of historical interpretations, such as film, virtual reality simulations and online museums, have found a growing audience and influence. History education has followed suit in Australia, with a range of multimodal sources commonly featured in history teaching programmes. Film has become an increasingly popular choice as teachers strive to engage a student population accustomed to multimodality, and with technological upgrades facilitating viewings in learning spaces (Donnelly, 2014a). As Sam Wineburg et al. (2007: 15) proclaimed over a decade ago:

If school history is to play a major role in shaping the consciousness of today's iPoded, YouTubed, Instant Messengerized, MySpace American [or Australian] youth, it must find new ways to engage the cultural curriculum that engulfs them. Failing to do so only guarantees school history's irrelevance into the next century.

A recent study was undertaken in Australia to explore how secondary school history teachers used multimodal historical representations, such as film, museums, virtual reality experiences and models, in their practice (Donnelly, 2018). This paper reports on the findings in relation to film (in the form of feature, documentary, docudrama 
and short clips) and argues that it has the potential to contribute to the historical consciousness of the watcher/learner. The paper proposes a model to illustrate the pedagogical mechanisms at work in these instances, and implementation strategies and practices are further examined by reference to two teaching protocol case studies (see Tables 1 and 2).

\section{Historical consciousness as an objective of history teaching}

Historical consciousness has been a focus of history education literature for decades, both in Europe and North America, and the discourse features varied attempts to define, model and elucidate the individual and collective impact of historical knowledge and understandings on decision-making in the present (Thorp, 2014). Indeed, historical consciousness is viewed by many as the primary purpose of studying history. Brian Hoepper (2006), an Australian academic, proposed six interconnected elements that represent historical understanding: focus, concepts, heuristics, evidence, epistemology, and values and their application. He argued that in concert these work to create a historical consciousness, a lens through which the individual can understand and navigate the present. Epstein (2000) saw the lens of historical consciousness enabling an individual to critically interpret their own bias, temporal, cultural, national and societal positionality, to understand issues of contemporary and historical concern such as racism, inequality, political instability and power. More recently, Kölbl and Konrad (2015) identify how global historical consciousness is needed to recognize diversity and increase an awareness of others.

The work of Jörn Rüsen $(1989,2004)$ and Peter Seixas $(1996,2005)$ among others has been influential in establishing the historical consciousness scholarly discourse. Rüsen proposed a typology composed of four levels of historical consciousness: traditional, exemplary, critical and genetic. At the traditional stage, historical knowledge is fixed and unquestioned, and values are seen as valid and consistent over time. The next proposed type, exemplary historical consciousness, sees time as changing, while human conduct remains constant. As such, exemplary historical consciousness views history as containing lessons to guide the future. At the critical stage of historical consciousness, the previous types are challenged and produce critical histories to question traditional moral values. The highest level is genetic historical consciousness, which conceives of time and value systems as dynamic. This form of historical consciousness is more sophisticated as it also acknowledges that the historical interpretation of the individual is a function of their temporal perspective (Lee, 2004; Rüsen, 1989, 2004). In the United Kingdom, Lee (2005) emphasized the role of historical literacy in historical understanding and its link to the development of historical consciousness, which he defines as an instrument with which individuals can create their own frameworks for understanding the past. Peter Seixas (2005) drew on Rüsen's typology of the four types of historical consciousness to develop a model linking historical consciousness to school contexts. In the development of this framework, Seixas (2005) linked this approach to his elaboration of the elements of history understanding that have been very influential in the evolution of the Australian history curriculum.

More recently, the handbooks edited by Metzger and McArthur Harris (2018) and Clark and Peck (2019) attest to the continuing interest in the topic among scholars from various backgrounds. This interest has been further demonstrated by the recent special issue of Journal of Curriculum Studies (Volume 51, Issue 6) devoted to historical 
consciousness and its workings in education. In particular, the work of Paul Zanazanian resonates with this paper. Zanazanian (2019) highlights the work of the sociocultural anthropologist James Wertsch on the role of narrative in understanding of the past, and points to memory and affect as having important roles in the development of historical consciousness. Memorability and affective impact are reported as the main reasons for the inclusion of historical film into teaching programmes (Donnelly, 2014a).

\section{The connection between history and the visual}

Studies of historical memory have found that individual recall and understanding of history is linked to collective memories gained through public history representations and social interactions (Clark, 2014; Létourneau, 2006; Landsberg, 2015) and that these interactions increasingly require visual, media, digital and internet literacy, and the ability to move with fluidity between the real, communication platforms and devices. It is these capabilities that allow individuals to interpret, act and participate in their own culture and society (Landsberg, 2015; Virta, 2007).

New technologies are changing how the world communicates. Now information and knowledge are being shared in an image-rich environment influenced by a broad range of media and social networking (Grushka and Donnelly, 2010). Decades ago, the famous American writer and philosopher Susan Sontag (1979: 3) prophesized that contemporary society's understanding of itself would move to be based on the image: 'The most grandiose result of the photographic enterprise is to give us the sense that we can hold the whole world in our heads - as an anthology of images.' Henri Lefebvre (1991), the French philosopher and sociologist, went further, maintaining that individuals possess a sort of imaginary museum, partially comprised of images from historical movies that have left an impression on us. He calls for historians to examine this image bank/imaginary museum and its influence on society's collective memory. Historian John O'Connor $(1990,2007)$ has long argued for the educational role of films, and stresses their value as representations of history and evidence of social and cultural change. He recommends that these 'moving image documents' are examined for their content, production context and their reception by society when released.

In Australia, research has clearly demonstrated the important role of the visual in connecting a society to its past. The three-year Australians and the Past project revealed that by far the most frequently nominated historical activities were watching historical movies or documentaries on television and looking at photographs (Hamilton and Ashton, 2003; Ashton and Hamilton, 2010). The Australian project was modelled on the US-based Presence of the Past project, which reported the finding that film gave a stronger connection with the past than school studies (Rosenzweig and Thelen, 1998).

\section{Film's impact on historical imagination and consciousness}

Films have the potential to support students in thinking historically by offering multiple perspectives and promoting historical empathy and the development of historical imagination (Rosenstone, 1995, 2001; Taylor and Young, 2003; Stoddard, 2007; Stoddard et al., 2017). At the core of the discipline of history is the interpretation of 'traces' and 'accounts of the past' (Seixas, 1996: 765). However, as R.G. Collingwood (1993) asserted in the 1940s, historians study what has already happened and they need a mechanism to reconstruct the past in the present. He called it the historical imagination. The role of imagination in the learning and understanding of history is 
one that needs careful consideration and management, particularly when using film (Donnelly, 2013; Stoddard et al., 2017).

It has been noted by several well-known researchers that there is tendency for history and filmic representations to become muddled in the memory and historical consciousness. This confusion was observed by Wineburg (2001) when he noted that some of his participants when asked about historical events, referenced popular films, such as Forrest Gump and Schindler's List, as supporting evidence for their attitudes and evaluations. Also, there appears to be a contradiction in student utilization of films as historical documents (Marcus, 2003; Paxton and Meyerson, 2002), as students were aware of the unreliability of films as historical sources and demonstrated a healthy scepticism of them, citing issues of motive and profit. But when the films were used in class, the students tended to accept the filmic presentation as accurate, and integrated them into their narratives of events and individuals. Marcus (2003) proposed that this contradiction between beliefs and practice was brought about by the teachers' pedagogical approach. This claim is supported by the earlier work of Seixas (1994), who found that students believed that the film Dances with Wolves (1990) provided a window to the past in its narrative of White-Native American relations until they viewed other films with different perspectives. After being exposed to alternative narratives, the students began to re-evaluate their uncritical view of Dances with Wolves and incorporate it into a more complex, nuanced understanding.

\section{Challenges of film in history pedagogy}

The effective utilization of film to teach history is not a simple matter, and it requires clear learning objectives and explicit teaching (Stoddard, 2007). Wineburg and Martin (2004) claim that effective use of film requires careful time allocation and explicit teaching; without these, film can become another 'distraction' to the examination and analysis of historical sources. They conclude that students should investigate and respond to film as a historical artefact to ensure the development of historical literacy skills.

The very nature of film production is an issue in the utilization of film for educational objectives. Films are often commercial enterprises and as such need to attract an audience. It can be the case that adherence to the historical evidence and narrative is set aside in favour of entertainment, with distortions, compressions and fictional additions commonplace. Perhaps the most insidious and difficult problem is that of presentism, that is, having characters in the past act and speak in the manner of contemporary society. This is a problem in the presentation of values, attitudes and societal roles of the past, which may jar with modern sensibilities (Weinstein, 2001). For example, many contemporary audiences may not be comfortable with the rigid codes of behaviour and limited expectation of independence that existed for women in some past, and indeed contemporary, societies. These narratives are therefore often 'updated' for the comfort of the contemporary audiences and the historical record falsified or misrepresented. These 'creative liberties' need to be explicitly exposed, assessed and amended in the minds of the learners, if films are going to be useful in the teaching and learning of history.

The use of film also has challenges of practical implementation. Modern films, especially feature films, are often too long to conform to the lesson structure of a typical high-school timetable. Viewing, discussing and analysing a film in its entirety can take up several weeks of lesson time. In many teaching environments, time is short because of the demands of content-heavy syllabuses and high-stake examination structures (Donnelly, 2014a). To counter this problem, many teachers show sections of 
films to illustrate particular teaching points, but using film clips can frustrate students who want to see the whole story and deny students the opportunity to fully engage with the film's narrative and production techniques (Metzger, 2010). Further, teachers have to contend with negative attitudes to film from within the school community and beyond. Many school administrators, parents and sometimes even colleagues fail to understand the educational value in using films in a history, or any other, class. Here, the confusion is between film as popular entertainment and as a historical artefact, and the teacher is commonly perceived as opting for an 'easy' lesson and derelict in their duty (Donnelly, 2014b).

\section{Research context, design and analysis}

Currently, the educational context for teaching history and utilizing films to teach history is complex and demanding. The Australian history syllabus prescriptions require learner attainment of historical understandings and the importance of their link to historical consciousness have been recognized in scholarly discourse. There has been an increase in technological accessibility of multimodal sources, but little in the way of teacher training in implementation (Donnelly, 2014b). Also, the integration of multimodal sources has been discouraged in some schools, with the result that teacher practice with film has been restricted (Donnelly, 2018). Further, few of the history teacher participants in this study were able to clearly define the term 'historical consciousness', and still fewer could recall the names of prominent scholars in the field. Despite this lack of clarity, many teachers were able to elucidate the importance of historical knowledge and understandings in the present and (unknowingly) agreed with Laville (2004) about the ways in which studying history gives learners an understanding of themselves as historical beings in a world built by past people and events. It was in this context that this study was enacted. This paper reports on the findings with regard to the research question:

When teaching history, how can film be used in the development of historical consciousness? Can stages be identified in this process?

The project used a three-phase design. The majority of participants were from the most populous Australian state of New South Wales, with smaller contributions from the other states and territories. Initial data were gathered from two surveys: one focused on teacher practices, attitudes and experiences of using film and other multimodal historical representations in history $(n=205)$; and the other on student experience with film and other multimodal historical representations in history $(n=230)$. The second phase of data gathering took the form of 25 semi-structured teacher interviews. The selected group volunteered from among the survey respondents. They were from a variety of teaching contexts, and had a diverse range of experiences with, and attitudes to, film in their teaching of history. In the third phase, case studies were undertaken by gathering further data from four of the interviewees by way of lesson observation and analysis of teaching plans and records. Two of these teaching plans are provided as Tables 1 and 2. Eventually, the project adopted an iterative design based on the grounded theory precepts, which saw the phases of coding, open, axial and selective, and the development of a logic paradigm or visual representation of the theory (Creswell, 2012). The data from all phases were coded using NVivo software, and analysis was undertaken by the development of 'trees' of interrelated ideas and themes. This paper reports on the findings concerning the use of historically based films, in the forms of feature films, documentaries, docudramas and short film clips, such as 
those sourced from YouTube. The model below is a synopsis of the findings in relation to the use of films in the history classroom and its link to historical consciousness.

\section{Findings: The synoptic model of historical film in history education}

The synoptic model (Figure 1) uses the data from the three phases of this project to trace the utility of historical films from viewing, to its pedagogical applications and to the world beyond school. It proposes pathways by which the filmic product can be embedded and utilized in the development of historical understanding, world view and consciousness. The model is divided into three domains: the viewing juncture, school life pedagogies, and world life. Discussion of these domains will be supported by reference to data from the project.

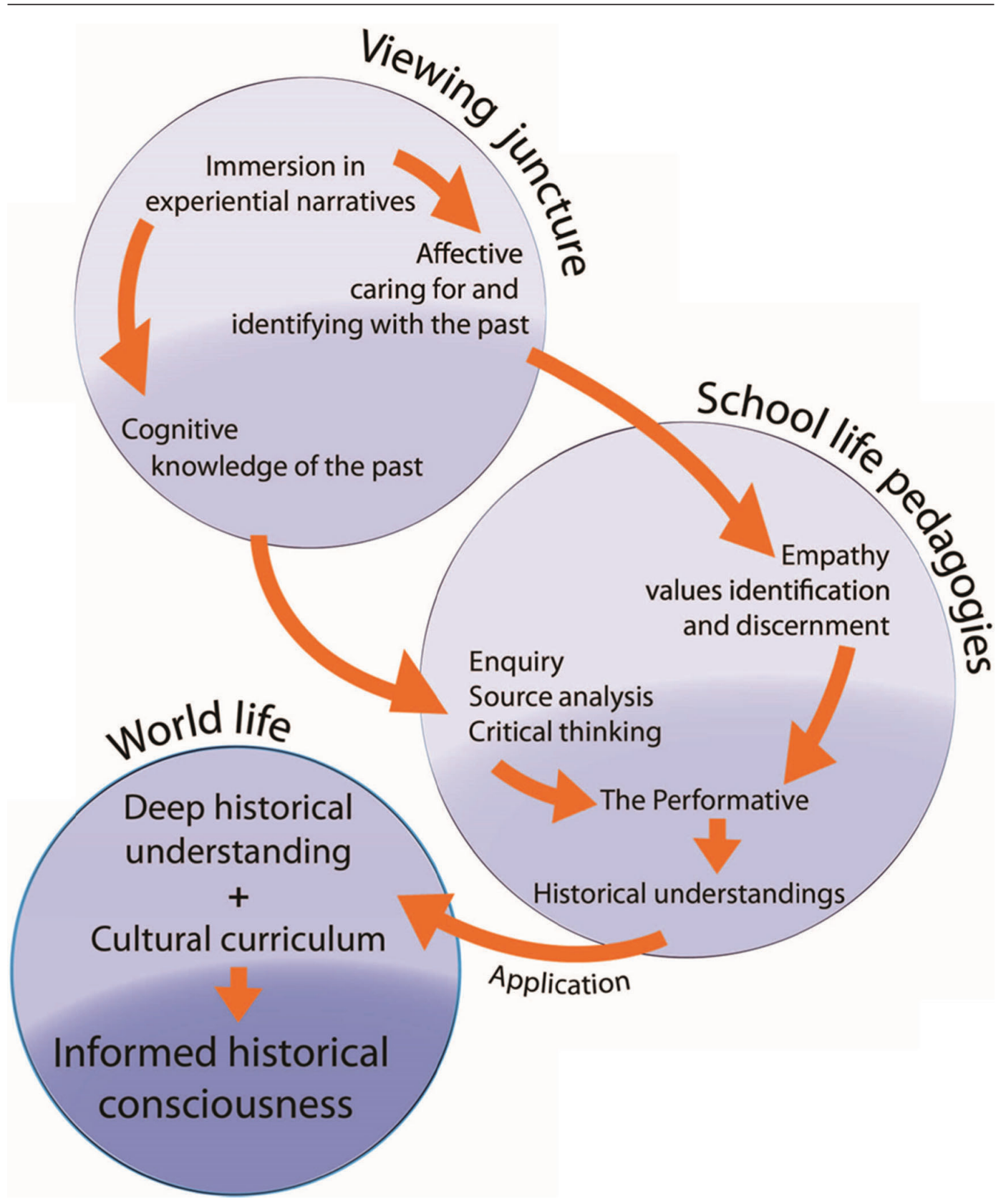

Figure 1: The role of historical film in history education and historical consciousness 


\section{The viewing juncture domain}

The viewing juncture domain makes the argument that the viewing of a historical feature is ideally an immersive experience during which the viewer is briefly transported to the past as recreated in the world of the film. This encounter has a dual and simultaneous impact on the viewer: cognitive and affective. Recent developments in cognitive neuroscience have clearly demonstrated that rational thought and decision-making processes are dependent on the affective response and that these neurological systems work in concert to create a functioning entity capable of critical thinking and judgement (Donnelly, 2013). Overwhelmingly, the participants in this research project have lauded historical films as engaging and memorable, and the data strongly support the contention that this trait of film emanates from the uniting of the cognitive and the affective in the filmic encounter.

The affective dimension of using historical films in history teaching functions in a close partnership with the intellectual challenge. It was strongly attested in the data that historical films were powerful vehicles for eliciting emotional responses from their audiences, and it has been argued that the structural and character familiarity of film for contemporary audiences encourages identification with characters and situations. This empathetic response was seen by the vast majority of teachers and students in this project as a major contributor to historical film's utility in the history classroom. In the teacher survey, the encouragement of empathy and the stimulating of historical imagination were cited as the strongest reasons (72 per cent). As one teacher explained, 'film is especially powerful for history as we cannot travel back in time so therefore going back through film is very useful'. On a similar theme, another teacher said: 'Film is how most gen [generation] $x, y, z$ access texts so it's a familiar genre, more emotive and with a multisensory impact to appeal to their imaginations. So many rich texts available it is difficult to choose.' However, many teachers saw the affective response as limited to the engagement, interest and memorability aspects of film viewing and reported little or no further exploitation.

Many teachers commented on the role of film in helping students construct a narrative of the past. One respondent commented: 'It is important for students to see how the story unfolds. History is story first and foremost and that is how students relate to it.' A number explained that the narrative becomes a springboard for investigation: 'I use the film narrative as a starter for research or to give a visual for already researched work. This provides opportunity for checking historical accuracy against other sources and identifying key figures.' One issue that was mentioned by several teachers was the power of film to impact on the memory of students and the problems that this can cause: 'Most [students] need to know the historical context first and will need to be able to separate the "poetic licence" from fact. Sensationalism is remembered above issues of historical importance.'

Linked to this theme was the notion that film helped learning in history because the narrative could be examined as a construction of the past and then embedded in a broader study of the evidence. As one teacher explained:

They [films] help in the understanding of the process of historical construction. Films put forward a particular historical interpretation in a way they [students] do not necessarily pick up in a written text. Things such as what is left out, selection of actors for particular parts and introduction of romance can be detected and motives for inclusion looked at. 
Another teacher supports this idea: 'When I'm evaluating a film as a source, I have focused viewing followed by discussion and comparison with other sources. It is vital to line up the film with other historical evidence.' A few teachers commented on the importance of critically examining the films to detect how the audience is being manipulated: 'I think it is important that the students understand that the visuals, music, characterizations and narrative of the film are designed to get them in. I have them note down the techniques used by the film-makers for later discussion.'

Film's ability to engage and to create interest was the most cited reason for using film in teaching history. This response was typical of a large number of respondents:

Kids enjoy the experience and become more involved in their learning. Students recall what they have seen and discussed rather than what they have just read. Film allows the teacher to refer back to particular scenes or incidents in their explanations and gives the students an initial frame of reference.

Film selection was seen as an important element of success and engagement. As one teacher put it:

Careful selection of the film is crucial - what was 'hip and happening' in 1976 may no longer be so today. It is important to find a film that the students can relate to, otherwise no matter how good it is they will not want to connect with it.

Another respondent had a similar opinion: 'Students do not always engage with a film. They complain and lose interest if they find the film corny, old, poorly made or acted or if it has old-fashioned visual effects.'

Many respondents have found that film helped their students identify with the past and develop emotional as well as intellectual connections. As one teacher related, 'I've watched a whole generation of students empathize with Aboriginal people because of watching Rabbit-Proof Fence and I've yet to get a single student volunteer to fight the way soldiers did in World War I thanks to Gallipoli.' Another teacher used the same films as examples of the power of film to take students back to a past world:

Most students don't understand the society of 1914, so showing Gallipoli explains in one film what could take a month of words and pictures. Same with Rabbit-Proof Fence. When they see the anguish of the parents and kids, they really know what the Stolen Generations is all about. It makes it more real to them and brings the topic to life and they will not forget.

It is proposed that the viewing juncture (see Figure 1) is the beginning of an intellectual trail. The viewer is given access to multisensory avenues from which to explore existence in another time and place. The naive will readily accept historical films as a window onto the past, but the more astute understand that these past worlds are creations and may be historically flawed fictions. This is the intellectual challenge for students, and the pedagogical quest for their teacher, when using historical films in the history classroom. Historical films can be valuable stimuli for enquiry and critical thinking, and they have been observed in this project to inspire high-order historical literacy skills and enthusiasm for exploring and understanding the past and its resonance in the 
contemporary. In these contemporary history classes, the cognition of the historian is modelled for the students, and they are given opportunities to experiment with the epistemological mechanisms of the discipline through enquiry and the construction of historical analysis and argument. Evaluating the filmic narrative against other sources of historical knowledge enriches and enlivens the exploration as original, more nuanced narratives and understandings are conceived and collaboratively scrutinized. This is a well-trodden pathway for scholarly discourse, and this project found several practitioners with highly developed understandings and methodologies who were achieving high-order learning outcomes with their students. However, these exemplars were exceptions, as the vast majority of practitioner practice narratives revealed little or no integration of historical films into the evidentiary debate and a lack of deep investigation of film as a historical representation.

\section{School life pedagogies}

The survey and interview data revealed that most history teachers in this project considered that the history classroom was not the domain for values considerations or that this agenda represented risk-taking beyond their mandate. Unquestionably, probing societal values from the past and considering their implementation in the present has the potential to cause controversy, and even parental and institutional sanctions, for teachers who work in a transparent and accountable learning environment (Donnelly, 2014b). However, the case studies phase of this project demonstrated the effectiveness of using film to drive a values and ethics agenda in history teaching. The work of Mrs Warner and Mrs Patterson is described below, and will be used to illustrate how the affective response to the filmic product can lead learners to values identification and discernment insights and a reflective selfevaluation of their own values, attitudes and actions (see unit plans in Tables 1 and 2). Although different in approach, both exemplars integrate film and other sources into the enquiry and have the students enact their knowledge and understandings in the making of a product - Snowy's diary and the Anzac Day speeches for Mrs Warner, and the discussion and essay response to question with stimulus material for Mrs Patterson.

\section{Mrs Warner's use of the film Gallipoli (1981)}

The work of Mrs Warner, as outlined in Table 1, is an example of the use of historical film to bring students to a greater understanding of how their lives are connected to past events. Mrs Warner utilized the power of film to create an environment in which past and contemporary issues were discussed, contrasted and analysed in the context of value identification and evaluation. According to Mrs Warner, this unit 'often strikes a chord with students. They have grown up with Anzac Day.' Peter Weir's Gallipoli (1981) was woven through the observed unit and used extensively to engage the students and as stimulus material to frame activities. To develop empathy and perspectivetaking skills, Mrs Warner had students produce diaries and opinion pieces from the standpoint of various characters in the films. As she said, 'Seeing how the other bloke thinks is an important skill for the students in their lives now and in the future.' For Mrs Warner, history education was about applying lessons learnt from exploring the past to encourage the development of sophisticated responses, attitudes and actions in the present. 
Table 1: Mrs Warner's Stage 5 Year 9 (14-15 year olds) Core Study - Depth Study 3: Australians at war: World Wars I and II (NSW History K-10 Syllabus, 76-7), integrating the film Gallipoli (1981)

\begin{tabular}{|c|c|c|}
\hline Week & Activity & Goal \\
\hline 1 & $\begin{array}{l}\text { Viewing of the landing scene from Gallipoli. } \\
\text { Focus question: How did Australians get to be } \\
\text { invading Turkey? Students take observational notes, } \\
\text { teacher-led whiteboard summary. } \\
\text { Where is Gallipoli? Why did the British want to attack } \\
\text { it? Research from map, internet and textbooks. }\end{array}$ & $\begin{array}{l}\text { Foundational knowledge } \\
\text { of the topic: the location } \\
\text { and the reasons for } \\
\text { Australian involvement. }\end{array}$ \\
\hline 2 & $\begin{array}{l}\text { Life at Gallipoli - class research under various } \\
\text { headings from film and textbooks. Observe identity } \\
\text { of soldiers from Gallipoli - Do they see themselves as } \\
\text { Australian or British? Source analysis and note-taking } \\
\text { from class discussion. } \\
\text { Focus question: What were the various reasons that } \\
\text { caused young Australian men to volunteer for this } \\
\text { war? }\end{array}$ & $\begin{array}{l}\text { Research Australian } \\
\text { soldiers in the First World } \\
\text { War: reasons for joining up } \\
\text { and living conditions. }\end{array}$ \\
\hline 3 & $\begin{array}{l}\text { Assessment task: Research essay - Living and fighting } \\
\text { conditions. } \\
\text { Viewing of } 25 \text { minutes of Gallipoli - Archie and Frank } \\
\text { in Australia before they join up. Motives for joining? } \\
\text { T chart after watching film and worksheet with the } \\
\text { headings - 'Reasons to join' and 'Evidence from the } \\
\text { film'. } \\
\text { Source analysis - recruitment and other posters. } \\
\text { Students create poster in small groups. Present and } \\
\text { explain to class. Class display. }\end{array}$ & $\begin{array}{l}\text { Understanding of multiple } \\
\text { perspectives. } \\
\text { To investigate the } \\
\text { propaganda through } \\
\text { posters. }\end{array}$ \\
\hline 4 & $\begin{array}{l}\text { How were the men trained for war? Watch Gallipoli } \\
\text { training in Egypt section. } \\
\text { Website investigation into relations between British } \\
\text { and Australians in this campaign. How accurate was } \\
\text { the portrayal in Gallipoli? } \\
\text { Class exercise: Postcard home from Egypt. } \\
\text { Newspaper from the home front. Class display. }\end{array}$ & $\begin{array}{l}\text { To examine the } \\
\text { preparation for the } \\
\text { campaign and the } \\
\text { relationship between the } \\
\text { British officers and the } \\
\text { Australian officers and } \\
\text { soldiers. }\end{array}$ \\
\hline 5 & $\begin{array}{l}\text { Visit to local war memorial site. Why do we have } \\
\text { so many of these memorials? Class examination of } \\
\text { memorials at Lake Macquarie. } \\
\text { Website research: What memorials and cemeteries } \\
\text { are there today at Gallipoli? }\end{array}$ & $\begin{array}{l}\text { Site study and explore } \\
\text { impact of the First World } \\
\text { War on home front, then } \\
\text { and now. }\end{array}$ \\
\hline 6 & $\begin{array}{l}\text { Watch last } 15 \text { minutes of Gallipoli. } \\
\text { Official documentation - source analysis: death } \\
\text { report, discharge papers. } \\
\text { Assessment task: Snowy's diary (Snowy is a character } \\
\text { in Gallipoli). Students have to write ten entries and } \\
\text { select four for grading. }\end{array}$ & $\begin{array}{l}\text { Verification of Gallipoli } \\
\text { using primary sources. } \\
\text { Encourage perspective- } \\
\text { taking and empathy. }\end{array}$ \\
\hline 7 & $\begin{array}{l}\text { Class test. } \\
\text { Assessment task - Anzac Day speech assignment. } \\
\text { Organization of class Anzac Day ceremony. } \\
\text { Presentation of top five Anzac Day speeches and five } \\
\text { selected entries from Snowy's diary. }\end{array}$ & $\begin{array}{l}\text { To test knowledge and } \\
\text { source analysis skills. To } \\
\text { link topic to the students' } \\
\text { lives and national } \\
\text { traditions. }\end{array}$ \\
\hline
\end{tabular}


An assessment item drawn from the film is Snowy's diary. In the film, Snowy is killed at Gallipoli; as he is dying, he asks his mates to give his mother his diary. Throughout the unit, the students had been set the task of writing ten diary entries from Snowy's point of view. Mrs Warner emphasized to the students the importance of the history in this exercise. As she told the class, 'the idea of this is not to spend time saying how Snowy feels but to explain what happened and what it was like for him and his friends'. There were some high-quality entries read, and the majority of students gained valuable insights from listening and having to judge their peers' efforts. Selected diary entries were presented to the whole school as part of the Anzac Day ceremony.

The last lesson began with viewing the last 15 minutes of Gallipoli, in which Frank failed in his attempt to save Archie and the others from having to go 'over the top' to certain death. The effect was profound. The class sat in silence as the credits rolled. One of the girls said: 'So did he really get killed, Miss? That's so sad.' A boy agreed: 'That's so stupid. They shouldn't have gone.' Mrs Warner then led the class in a discussion that ranged from military discipline and obeying orders, to changes in military technology, the number of casualties in the First World War and its impact on Australia, and the futility of war and its commemoration. Although Mrs Warner had brought other work, it remained on the teacher's desk, as all of the class engaged in the discussion until the end of the period. Afterwards, Mrs Warner commented:

That went well. It is always the same, you have some taking out tissues, or trying to have an excuse to get out of the room because they've got tears coming, and the boys get noticeably quieter. That last shot has a very dramatic impact and leads so well into talking about the reality of war. They were worked up, weren't they?

\section{Mrs Patterson's use of the film The Motorcycle Diaries (2004)}

As can be seen in her unit plan in Table 2, Mrs Patterson's teaching unit culminated in a structured class discussion. Mrs Patterson's class discussions were a well-established learning routine. They were inclusive class events in which all the Year 12 (final year of high school) girls were expected to contribute, and they were 'built up' as the climax of the unit on Che Guevara. The students had pre-reading of short excerpts with comprehension and evaluative questions. The excerpts were composed of: varying opinions of Guevara; reactions to the film under study, The Motorcycle Diaries (2004); and the mythologizing of individuals as heroes. The day before, Mrs Patterson gave the students focus questions for the discussion: 'Should we love Che?' and 'Was he a hero?' She set for homework that the students should 'jot down your ideas, for and against'. The actual discussion was passionately debated by the small class, with the girls expressing a variety of opinions. Mrs Patterson allowed the girls to direct the discussion, but occasionally she asked the speaker, 'What makes you say that?' or addressed the class, asking, 'Can someone expand on that idea?' 
Table 2: Mrs Patterson Stage 6 Year 11 (16-17 year olds) Theme 11: The individual in history: Concept of the great person in history (Queensland Modern History Senior Syllabus, 38), integrating the film The Motorcycle Diaries (2004)

\begin{tabular}{|c|c|c|}
\hline Week & Activity & Goal \\
\hline 1 & $\begin{array}{l}\text { Close examination of article: 'Hegel's Lectures on the } \\
\text { Philosophy of History'. } \\
\text { Mind map - implications of the 'great man theory'. } \\
\text { Research and develop timeline of Che Guevara. }\end{array}$ & $\begin{array}{l}\text { Introduce the concept of the } \\
\text { 'great man theory'. }\end{array}$ \\
\hline 2 & $\begin{array}{l}\text { Mapping: Where in the world is Che? } \\
\text { Watch The Motorcycle Diaries. } \\
\text { Take notes and develop ideas on depiction of Che. }\end{array}$ & $\begin{array}{l}\text { Locate geographical setting. } \\
\text { Watch and analyse the film. }\end{array}$ \\
\hline 3 & $\begin{array}{l}\text { Class discussion: How is Che Guevara depicted in } \\
\text { the film? Spider diagram. } \\
\text { Examine collection of Che merchandise: How is Che } \\
\text { Guevara depicted in the artefacts? } \\
\text { What is mythology of Che? Class construct a list. }\end{array}$ & $\begin{array}{l}\text { Draw conclusions about } \\
\text { depiction in film. } \\
\text { Examine image of Che in } \\
\text { contemporary society. }\end{array}$ \\
\hline 4 & $\begin{array}{l}\text { Close examination of article: Berman, P., 'The cult of } \\
\text { Che: Don't applaud The Motorcycle Diaries'. } \\
\text { Class discussion: Should we love Che? } \\
\text { Students write paragraphs. How would you describe } \\
\text { Berman's attitude to Che? What objective evidence } \\
\text { does Berman offer to substantiate his position? }\end{array}$ & $\begin{array}{l}\text { Introduce an alternative view } \\
\text { of Che. }\end{array}$ \\
\hline 5 & $\begin{array}{l}\text { Close examination of article: Bertram, C., 'Portraying } \\
\text { Guevara'. Students annotate and develop summary } \\
\text { of ideas from all material so far. } \\
\text { Answer question: Is Che Guevara a 'great man' } \\
\text { according to the theory? }\end{array}$ & $\begin{array}{l}\text { Clarify ideas about Che - } \\
\text { both positive and negative. } \\
\text { Apply 'great man' theory to } \\
\text { Che and make judgements. }\end{array}$ \\
\hline 6 & $\begin{array}{l}\text { Student research: What other sources can you find } \\
\text { about Che? What do they add to the argument? }\end{array}$ & $\begin{array}{l}\text { Independent research } \\
\text { allowing for exploration of } \\
\text { the topic. }\end{array}$ \\
\hline 7 & $\begin{array}{l}\text { Teacher-led class summary developed. } \\
\text { Students modify their research findings to include } \\
\text { any useful sources. } \\
\text { Essay: How is Che Guevara depicted in the historical } \\
\text { record? }\end{array}$ & $\begin{array}{l}\text { Class collaboration allows } \\
\text { for modification of individual } \\
\text { research positions. }\end{array}$ \\
\hline 8 & $\begin{array}{l}\text { Close reading of article: Munslow, A., 'What is } \\
\text { history?' Students answer questions. } \\
\text { Class discussion of modernism and postmodernism } \\
\text { in history. } \\
\text { Class discussion and summary: Can a feature film } \\
\text { be a history? Evaluate The Motorcycle Diaries as a } \\
\text { historical source. }\end{array}$ & $\begin{array}{l}\text { Discussion and debate to } \\
\text { develop understanding of } \\
\text { history as a discipline. } \\
\text { Apply ideas of the nature of } \\
\text { history to film as a historical } \\
\text { source. }\end{array}$ \\
\hline 9 & $\begin{array}{l}\text { Examination of children's educational website } \\
\text { BrainPOP as a source for Che. Is it a good source for } \\
\text { target audience? } \\
\text { Reflection: What problems face the Che historian? } \\
\text { Class discussion. }\end{array}$ & $\begin{array}{l}\text { Students evaluate material } \\
\text { from a position of knowledge. } \\
\text { Students reflect on problems } \\
\text { with Che Guevara's } \\
\text { historiography and the } \\
\text { contestable nature of history }\end{array}$ \\
\hline 10 & $\begin{array}{l}\text { Class summary in preparation for examination. } \\
\text { Should we love Che? Whiteboard summary. } \\
\text { Knowledge and response to stimulus examination. }\end{array}$ & $\begin{array}{l}\text { Prepare students for } \\
\text { examination and summarize } \\
\text { issues. } \\
\text { Learning is tested and } \\
\text { assessed. }\end{array}$ \\
\hline
\end{tabular}


As the discussion was drawing to an end, Mrs Patterson brought the class back to the focus questions and used a $T$ chart to summarize the ideas and evidence raised. These notes were then used as the basis for an essay response, 'Is the presentation of Che Guevara in the film The Motorcycle Diaries (2004) an accurate portrait or part of the mythology of a revolutionary?' At the end of the lesson, Mrs Patterson focused the attention of the class on the historical understanding that they had 'discovered', that is, that history is contestable and interpretative. As she put it:

So girls, you need to look beyond the good-looking hero in the film and the reputation and merchandizing [points to stylized image of Che on the wall], look at the evidence and decide what is a hero and was Che one?

As can be seen in this example, in the hands of a skilful practitioner, a film can be a useful tool to demonstrate the contestable nature of historical interpretation, and class discussions can be lively shared-attention events in which historical arguments are debated and evaluated.

Mrs Patterson was the only teacher who spoke about having students consider the impact of film on historical consciousness and question the role of film in history teaching. As she explains, 'we're looking at the idea that if students, if people, leave a film thinking this is what the history was, is that problematic?' The class undertook an evaluation of the film, The Motorcycle Diaries, to determine if it was claiming to be historically reliable and then compared the representation with other sources to ascertain its veracity. The study centred on focus questions, 'How is Che represented in the film?' and 'Should we love Che?' Mrs Patterson explained the outcomes:

The girls decided that the film was making the claim to be history but favoured Che and contributed to his mythology. They concluded that it was important for them to study film and that film should be used in history teaching. I think it is important for them to see underlying ideologies and attitudes and how that affects representations of history on film.

\section{World life domain}

The world life domain encompasses the world of the students beyond the school. It is the most speculative of the domains, as the focus of this research has been on the school learning environment. However, a number of survey respondents commented on the importance of 'outside influences' on their students' attitude to studying history. Several of the interviewees reflected on their impact beyond the classroom and presented their vision of how the skills gained from secondary school history studies can underpin lifelong understandings and perspectives. Mr Murray, one of the most eloquent of the interviewees, expressed the views of several history teachers in the project:

I think that students can recall all the factual information they like, they do well in exams, but if they haven't got any empathy or appreciation for the people and the events of the past, they won't really gain a true history experience. Movies are great for this. When they go out into the world and they go to a museum or go overseas or travel around and actually engage in the current world, they can understand where it's actually come from and know what it means for them today. I hope that's what they get out of my class. 
In the Student Experience Survey of Film and History $(n=230)$, the vast majority of student respondents (80 per cent) found that some historical films helped their memory and recall of history. In and outside the school context, these filmic narratives and images lingered in their consciousness: 'What happens in a movie can be related to actual history and it will stick in your mind'; 'Movies are a more relaxed way of learning and it helps things soak in, and images with words and dialogue helps heaps.'

Most comments about strong recollections from film viewings pointed to engagement or the visual impact of film. These laconic but compelling remarks stress the importance of engagement to student learning: 'Cause if it's a good movie you get into it'; 'Cause it plays back in my mind'. And this significant concession from a self-confessed uninterested student: 'I actually pay attention to the movie, not much else.' Some others were a little more analytical, giving credit to the multimodal nature of film to explain film's resonance. The following express the sentiments of many: 'I think that movies help because of the visual and audio stimulus'; 'They [films] help with photography and sound to imprint in the mind.' One student remarked that he found historical presentation in film to be both time efficient and thorough: 'Yes, because I learn better off pictures. Like a picture can say a thousand words in a little time and still show deepness.'

A smaller group pointed to the emotional journey that they vicariously experienced while watching film (5 per cent). These responses either cited 'seeing' the past or identifying with the characters as the reasons for memory retention. Several students argued that relating to the plight of characters was a key factor: 'Films create an emotional connection with the topic, and I remember the characters and how they react to things'; 'It's cool to watch movies. You feel sad and happy with the people you are watching and remember what went on.' These two remarks emphasize the importance of seeing: 'Yes, movies are good, like what it looked like back then and they make me feel like I was there sometimes. Because you see and hear it and it gives you emotions'; 'It's fun and I can see what things were like, like in Gallipoli, you can read but it was better than just reading.'

When asked if watching a film motivated them to find out more about the topic or historical period, a little under a third of students responded that the viewing of some historical films prompted them to explore the topic independently outside the classroom. Most sought extra information from the internet. These are three good examples of this type of response: 'Yes, after we watched Gallipoli, I wanted to know how many died, so I Googled it'; 'After Marie Antoinette, [I] went to the internet to find out more about the French Revolution'; and 'When we did Pocahontas, I looked up the internet and found out that she died of smallpox, which they never showed in the movie.' One student recalled visiting a virtual museum: 'Yes, I watched Phar Lap at home and went to see Phar Lap in a museum on the internet.' For another, it was a topic of conversation at home: 'After watching Gladiator, I Googled it and talked to my mum about it.'

Sometimes viewing one film motivated students to seek out other films set in the same time: 'I watched A Knight's Tale and I like that time in history, so I watched some other Middle Ages movies and I checked on the net about tournaments to find out more.' Two students reported that this viewing of a number of films set in a particular time or around a historical event was encouraged and facilitated by the history teacher: 'Some movies we can't watch at school but our teachers tell us what they are. Some I've gone and watched or have already seen and you have a better understanding of the subject from what you've learnt in class.' And from another enthusiastic student: 
When we did our Vietnam topic, I watched Full Metal Jacket cos miss said it in class. I like Vietnam War stuff and looking at weapons and miss and I was talking about some movies and I watched them. She also told me about The Killing Fields, and I watched it, and it was good.

The last domain of the diagram presents the idea of a historical lens that can be used to navigate the present. Students armed with their school-learnt historical knowledge and understandings apply these to the lived experience, their world life. Multiple applications authenticate their historical understandings and deepen the affective and cognitive connections. The findings support the use of a systematic staged approach to integrating film into teaching programmes in which the affective and cognitive impacts of the filmic form are used to examine the topic under study. The viewing experience is extended in the classroom with explicit analysis of the ethical dimensions, coupled with comparison with other primary and secondary sources.

The term 'deep historical understanding' has been adapted from the New South Wales Quality Teaching Model. Here, deep understanding is defined as 'profound and meaningful understanding of central ideas and the relationships between and among those central ideas' (NSW Department of Education and Training, 2003: 11). In the context of the synoptic model used in this research, deep historical understanding means that the various contributors to historical understanding have been integrated into a sophisticated conceptual framework. This framework, however, does not exist in a vacuum, but is impacted by innumerable sources of historical information and disinformation. The cultural curriculum of the model refers to these societal contributors to a sense of the past, such as film, television, family stories and heirlooms, photographs, museums, art galleries, monuments, national commemorative practices, travel experiences, fiction and non-fiction books, historical societies, websites and social media exchanges (Landsberg, 2015). All these are part of the cacophony of voices that speak to the individual of the past in the present, and it is the critical evaluation of this multitude that leads to an informed historical consciousness and aligns with Rüsen's (2004) genetic historical consciousness. As Hoepper (2006) would have it, 'a lens for understanding the world and a vital part of the framework that empowers the individual to think and act'.

\section{Conclusion}

This research project concluded that film can be effectively used as a stimulus to examine past and present issues, and that school life pedagogies can be given relevance beyond the classroom. This project found examples of effective practice with film as elaborated in this paper, but examination of the entire data set reveals that these teachers were the exceptions. In fact, the majority of the participating teachers tended to under-utilize film, with many reporting little or no integration of the film into the historical study and few attempts to connect the school studies beyond school. The project found that films were mostly used as an 'attention grabber' or introduction to the era or topic in history classrooms, and concluded that many practitioners failed to capitalize on film's higher-order potentials.

This failure is a significant one, as history in secondary school is called to be more than just good stories, source analysis exercises or writing essays. History teachers are tasked with helping students create a consciousness of the role of history in the present and with working to provide society with an informed citizenry. The New South Wales Syllabus for the Australian Curriculum: History Year K-10 (Board of Studies NSW, 2012: 12) states its aim as to 'develop a critical understanding of the 
past and its impact on the present, to develop the critical skills of historical inquiry and to enable students to participate as active, informed and responsible citizens'. At a time when the populations of Western societies demonstrate mass disillusionment with their governmental institutions (Donnelly, 2008), and technology and societal trends emphasize the individual (Twenge, 2006), history teachers are commissioned to arm their students with a consciousness of history that can be used to navigate the present. History teachers, then, are called to balance the cognitive with the affective, for without feeling there will be no active commitment to 'the common good' (Barton and Levstik, 2004).

History teachers' attraction to film in their practice testifies to the importance of engagement for learning, to an appreciation of the powerful appeal of the multisensory narrative to the historical imagination, and to the role of empathy in an enacted value system. The combined intellectual and affective responses can be harnessed to develop the epistemological skills and understandings of a historian and citizen. History teachers are charged by their education systems with empowering and impassioning the future citizenry to be knowledgeable and actively involved in their local, national and international communities and to contribute to the development of their students' historical consciousness. This consciousness creates a historical lens through which the world can be critically interpreted, and it is vital for informed judgement and participation. Again, Mr Murray's comment encapsulates the undertaking:

I think gaining an appreciation and an empathy for the past is also of great importance so that students can see that perhaps the issues they're going through right now, or the world issues that they see have been dealt with in the past ... I think it helps them work out how they're going to engage with the world as well, then I think they have really learnt something.

\title{
Notes on the contributor
}

Debra Donnelly is a history educator and researcher in the School of Education at the University of Newcastle, Australia, working with pre-service teachers in both undergraduate and postgraduate programmes. Dr Donnelly's research interests centre on the role of the visual and media in the development of historical and global consciousness in an age of ever-increasing access through modern technology, and seek to explore and clarify the relationship between teacher conceptual frameworks of understanding, problematic knowledge and memory, and pedagogical practice.

\section{Filmography}

\author{
Dances with Wolves (US 1990, Kevin Costner) \\ Forrest Gump (US 1990, Robert Zemeckis) \\ Full Metal Jacket (GB/US 1987 Stanley Kubrick) \\ Gallipoli (AU 1981, Peter Weir) \\ Gladiator (GB/US 2000, Ridley Scott) \\ The Killing Fields (GB 1984, Roland Joffé) \\ A Knight's Tale (US 2001, Brian Helgeland) \\ Marie Antoinette (FR/US/JP 2006, Sofia Coppola) \\ The Motorcycle Diaries (AR/BR/US/CL/PE/GB/DE/FR 2004, Walter Salles) \\ Phar Lap (AU 1983, Simon Wincer) \\ Pocahontas (US 1995, Mike Gabriel and Eric Goldberg) \\ Rabbit-Proof Fence (AU 2002, Phillip Noyce) \\ Schindler's List (US 1993, Steven Spielberg)
}




\section{References}

Ashton, P. and Hamilton, P. (2010) History at the Crossroads: Australians and the past. Ultimo: Halstead Press.

Barton, K.C. and Levstik, L.S. (2004) Teaching History for the Common Good. Mahwah, NJ: Lawrence Erlbaum Associates.

Board of Studies NSW (2012) NSW Syllabus for the Australian Curriculum: History K-10 Syllabus. Sydney: Board of Studies NSW.

Clark, A. (2014) 'Inheriting the past: Exploring historical consciousness across generations'. Historical Encounters: A Journal of Historical Consciousness, Historical Cultures, and History Education, 1 (1), 88-102.

Clark, A. and Peck, C.L. (eds) (2019) Contemplating Historical Consciousness: Notes from the field. New York: Berghahn Books.

Collingwood, R.G. (1993) The Idea of History. Ed. Van der Dussen, J. Rev. ed. Oxford: Clarendon Press.

Creswell, J.W. (2012) Educational Research: Planning, conducting, and evaluating quantitative and qualitative research. 4th ed. Boston: Pearson.

Donnelly, D. (2008) 'Role-playing, politics, citizenship and dressing up: Year 10's re-creations in the 1972 "It's Time" election'. Paper presented at the Social Educators Association of Australia (SEAA) Biennial Conference, Newcastle, New South Wales, 20-22 January 2008.

Donnelly, D. (2013) 'Teaching history using feature films: Practitioner acuity and cognitive neuroscientific validation'. International Journal of Historical Learning, Teaching and Research, $12(1), 16-27$.

Donnelly, D. (2014a) 'Using feature films in teaching historical understanding: Research and practice'. Agora, 49 (1), 4-12.

Donnelly, D. (2014b) 'Using feature film in the teaching of history: The practitioner decision-making dynamic'. Journal of International Social Studies, 4 (1), 17-27.

Donnelly, D.J. (2018) 'Contemporary multi-modal historical representations and the teaching of disciplinary understandings in history'. Journal of International Social Studies, 8 (1), 113-32.

Epstein, T. (2000) 'Adolescents' perspectives on racial diversity in US history: Case studies from an urban classroom'. American Educational Research Journal, 37 (1), 185-214.

Grushka, K. and Donnelly, D. (2010) 'Digital technologies and performative pedagogies: Repositioning the visual'. Digital Culture and Education, 2 (1), 83-102.

Hamilton, P. and Ashton, P. (2003) 'At home with the past: Background and initial findings from the National Survey'. Australian Cultural History, 22, 5-30.

Hoepper, B. (2006) 'Historical literacies'. Paper presented at the Social Educators Association of Australia (SEAA) National Conference, Brisbane, 13-15 January.

Kölbl, C. and Konrad, L. (2015) 'Historical consciousness in Germany: Concept, implementation, assessment'. In Ercikan, K. and Seixas, P. (eds) New Directions in Assessing Historical Thinking. New York: Routledge, 17-28.

Landsberg, A. (2015) Engaging the Past: Mass culture and the production of historical knowledge. New York: Columbia University Press.

Laville, C. (2004) 'Historical consciousness and historical education: What to expect from the first for the second'. In Seixas, P. (ed.) Theorizing Historical Consciousness. Toronto: University of Toronto Press, 165-82.

Lee, P. (2004) '"Walking backwards into tomorrow": Historical consciousness and understanding history'. International Journal of Historical Learning, Teaching and Research, 4 (1), 1-46.

Lee, P. (2005) 'Historical literacy: Theory and research'. History Education Research Journal, 5 (1), 29-40.

Lefebvre, H. (1991) Critique of Everyday Life. Trans. Moore, J. London: Verso.

Létourneau, J. (2006) 'Remembering our past: An examination of the historical memory of young Québécois'. In Sandwell, R.W. (ed.) To the Past: History education, public memory, and citizenship in Canada. Toronto: University of Toronto Press, 70-87.

Marcus, A.S. (2003) 'Celluloid Blackboard: Teacher practices with film and students' historical understanding'. Unpublished PhD thesis, Stanford University.

Metzger, S.A. (2010) 'Maximizing the educational power of history movies in the classroom'. The Social Studies, 101 (3), 127-36.

Metzger, S.A. and McArthur Harris, L. (eds) (2018) The Wiley International Handbook of History Teaching and Learning. Hoboken, NJ: Wiley-Blackwell. 
NSW Department of Education and Training (2003) Quality Teaching in NSW Public Schools: Discussion paper. Sydney: NSW Department of Education and Training.

O'Connor, J.E. (1990) Image as Artifact: The historical analysis of film and television. Malabar, FL: Robert E. Krieger.

O'Connor, J.E. (2007) 'Murrow confronts McCarthy: Two stages of historical analysis for film and television'. In Marcus, A.S. (ed.) Celluloid Blackboard: Teaching history with film. Charlotte, NC: Information Age Publishing, 17-39.

Paxton, R.J. and Meyerson, P. (2002) 'From "Birth of a Nation" to "Pearl Harbor": The influence of a movie's perspective on students' historical understandings'. Paper presented the American Educational Research Association (AERA) Annual Meeting, New Orleans, 1-5 April 2002.

Rosenstone, R.A. (1995) Visions of the Past: The challenge of film to our idea of history. Cambridge, MA: Harvard University Press.

Rosenstone, R.A. (2001) 'The historical film: Looking at the past in a postliterate age'. In Landy, M. (ed.) The Historical Film: History and memory in media. New Brunswick, NJ: Rutgers University Press, 50-66.

Rosenzweig, R. and Thelen, D. (1998) The Presence of the Past: Popular uses of history in American life. New York: Columbia University Press.

Rüsen, J. (1989) 'The development of narrative competence in historical learning: An ontogenetic hypothesis concerning moral consciousness'. History and Memory, 1 (2), 35-59.

Rüsen, J. (2004) 'Historical consciousness: Narrative structure, moral function, and ontogenetic development'. In Seixas, P. (ed.) Theorizing Historical Consciousness. Toronto: University of Toronto Press, 63-85.

Seixas, P. (1994) 'Confronting the moral frames of popular film: Young people respond to historical revisionism'. American Journal of Education, 102 (3), 261-85.

Seixas, P. (1996) 'Conceptualizing the growth of historical understanding'. In Olson, D.R. and Torrance, N. (eds) The Handbook of Education and Human Development. Cambridge, MA: Blackwell, 765-83.

Seixas, P. (2005) 'Historical consciousness: The progress of knowledge in a postprogressive age'. In Straub, J. (ed.) Narration, Identity, and Historical Consciousness. New York: Berghahn Books, 141-59.

Sontag, S. (1979) On Photography. New York: Dell Publishing Company.

Stoddard, J.D. (2007) 'Attempting to understand the lives of others: Film as a tool for developing historical empathy'. In Marcus, A.S. (ed.) Celluloid Blackboard: Teaching history with film. Charlotte, NC: Information Age Publishing, 187-214.

Stoddard, J., Marcus, A.S. and Hicks, D. (eds) (2017) Teaching Difficult History through Film. New York: Routledge.

Taylor, T. and Young, C. (2003) Making History: A guide for the teaching and learning of history in Australian schools. Melbourne: National Centre for History Education.

Thorp, R. (2014) 'Towards an epistemological theory of historical consciousness'. Historical Encounters: A Journal of Historical Consciousness, Historical Cultures, and History Education, 1 (1), 20-31.

Twenge, J.M. (2006) Generation Me: Why today's young Americans are more confident, assertive, entitled - and more miserable than ever before. New York: Free Press.

Virta, A. (2007) 'Historical literacy: Thinking, reading and understanding history'. Journal of Research in Teacher Education, 14 (4), 11-25.

Weinstein, P.B. (2001) 'Movies as the gateway to history: The history and film project'. The History Teacher, 35 (1), 27-48.

Wineburg, S. (2001) Historical Thinking and Other Unnatural Acts: Charting the future of teaching the past. Philadelphia: Temple University Press.

Wineburg, S. and Martin, D. (2004) 'Reading and rewriting history'. Educational Leadership, 62 (1), 42-5.

Wineburg, S., Mosborg, S., Porat, D. and Duncan, A. (2007) 'Forrest Gump and the future of teaching the past'. Phi Delta Kappan, 89 (3), 168-77.

Zanazanian, P. (2019) 'Examining historical consciousness through history-as-interpretivefilter templates: Implications for research and education'. Journal of Curriculum Studies, 51 (6), 850-68. 